\title{
Subordinasi Anak Perempuan Dalam Keluarga
}

\author{
Suarni \\ Muhammad Nawir \\ Universitas Muhammadiyah Makassar \\ muhammadnawir@unismuh.ac.id \\ Risfaisal \\ Universitas Muhammadiyah Makassar \\ rsisfaisal@unismuh.ac.id
}

\begin{abstract}
ABSTRAK
Setiap keluarga yang terdapat dalam masyarakat memiliki peran dan status yang berbeda antara satu dengan yang lain baik peran ayah, ibu dan anak. Namun biasa terjadi subordinasi antar jenis kelamin dalam keluarga antara anak laki-laki dengan anak perempuan.. Jenis penelitian ini adalah metode kualitatif deskriptif, pengumpulan data digunakan dengan cara observasi, wawancara, teknik dokumentasi dari hasil foto dan arsip yang dimiliki oleh pemerintah setempat. Dalam penelitian ini, yang menjadi sasaran penelitian adalah pertama anak perempuan yang mengalami subordinasi, kedua masyarakat yang dianggap bisa memberikan informasi atau data yang sesuai dengan penelitian.Hasil penelitian ini menunjukkan bahwa, perempuan yang mengalami subordinasi dalam keluarga disebabkan oleh dua faktor yaitu faktor kodrat (nuture) yang merupakan perbedaan laki-laki dan perempuan yang ketentuan dari tuhan dan faktor budaya atau konstruksi sosial (nurture) merupakan perbedaan laki-laki dan perempuan yang dibentuk oleh masyarakat dan lingkungan sekitar. Yang merupakan dampak negatif subordinasi perempuan yaitu membatasi perempuan untuk mendapatkan akses dalam berkiprah di dunia publik sedangkan dampak positifnya yaitu memberikan semangat bagi kaum perempuan untuk memperjuangkan hak dan posisi yang sama seperti kaum lakilaki.
\end{abstract}

Kata Kunci : Ketidakadilan, Subordinasi, Anak Perempuan.

\section{PENDAHULUAN}

Masyarakat adalah sekelompok orang yang membentuk sebuah sistem semi tertutup (atau semi terbuka), dimana sebagian besar interaksi adalah antara individuindividu yang berada dalam kelompok tersebut. Masyarakat adalah sebuah komunitas yang interdependen (saling tergantung satu sama lain). Sehingga dapat disimpulkan bahwa masyarakat adalah masyarakat yang hidup bersama disuatu wilayah tertentu dalam waktu yang cukup lama yang saling berhubungan dan saling berinteraksi dan mempunyai kebiasaan, tradisi, sikap, dan perasaan persatuan yang sama.Keluarga merupakan lingkungan sosial pertama yang dikenal oleh manusia. Dalam keluarga, manusia belajar untuk mulai berinteraksi dengan orang lain. Oleh karena itulah umumnya orang banyak menghabiskan waktunya dalam lingkungan keluarga. Sekalipun keluarga merupakan lembaga sosial yang ideal guna menumbuh kembangkan potensi yang ada pada setiap 
individu, dalam kenyataannya keluarga sering kali menjadi wadah bagi munculnya berbagai kasus penyimpangan atau aktivitas ilegal lain sehingga menimbulkan kesengsaraan atau penderitaan, yang dilakukan oleh anggota keluarga satu terhadap anggota keluargalainnya yang dikenal dengan istilah diskriminasi gender.

Di Desa Perangian Kecamatan Baraka Kabupaten Enrekang Perempuan dipandang sebagai makhluk lemah, yang hanya bisa menangis ketika menghadapi permasalahan. Kesan ini mengakar kuat dalam masyarakat di Desa Perangian Kecamatan Baraka Kabupaten Enrekang, mulai dari anak-anak, remaja, hingga dewasa memiliki pemahaman yang sama tentang hal ini. Tangisan perempuan merupakan sesuatu yang lazim dan biasa dalam kehidupan keseharian.Tak bisa dipungkiri, hal ini merupakan hasil pembentukan budaya yang tertanam sejak kecil. Seorang anak perempuan diizinkan untuk mengekspresikan perasaannya melalui tangisan, sedangkan jika anak laki-laki yang menangis orang dewasa akan segera menghardik dan mengatakan bahwa tidak pantas laki-laki menangis. Tanpa disadari, hal ini terbawa dalam kehidupan selanjutnya, meski telah dewasa perempuan terbiasa mengekspresikan perasaannya melalui tangisan sehingga muncul anggapan bahwa perempuan identik dengan sifat cengeng dan emosional sedangkan laki-laki tidak demikian.

\section{LANDASAN TEORI}

Masyarakat sering dikenal dengan istilah society yang membentuk berarti sekumpulan orang yang membentuk sistem yang terjadi komunikasi dalam kelompok tersebut. Menurut Wikipedia, kata masyarakat sendiri diambil dari bahasa Arab, musyarak.Masyarakat juga biasa diartikan sebagai sekelompok orang yang saling berhubungan dan kemudian membentuk kelompok yang lebih besar, biasanya masyarakat juga diartikan sebagai sekelompok orang yang hidup dalam satu wilayah dan hidup teratur oleh adat didalamnya.

Perempuan dan laki-laki berbeda dalam kodratnya.Perbedaan secara kodrati ini tidak membedakan perempuan dan laki-laki dalam hal kedudukan namun menentukan perannya dalam kehidupan.Dari segi fungsi reproduksi perempuan memungkinkan mengandung calon keturunannya karena perempuan memiliki rahim yang tidak dimiliki oleh laki-laki.Demikian juga dalam hal pengasuhan dan keberlangsungan bayi saat masih kecil, perempuan dianugerahi kemampuan untuk menyusui dan perasaan kasih sayang dan ketahanan tubuh yang lebih dibandingkan dengan laki-laki. 
Perbedaan yang ada antara wanita dengan pria seharusnya tidak menjadi sebuah masalah yang dapat menyebabkan kesenjangan diantara keduanya.Banyak pandangan yang seakan-akan menilai bahwa posisi wanita selalu lebih rendah dibandingkan dengan pria.Pria memiliki wewenang yang lebih banyak daripada wanita dalam segala hal, termasuk di dalam sebuah keluarga.Ada beberapa faktor yang menyebabkan perbedaan itu terjadi.Faktor biologis atau genetis merupakan suatu hal yang mutlak dan tidak dapat dirubah karena sudah berasal dari lahir.Sedangkan faktor lingkungan berhubungan dengan adanya perbedaan peranan antara wanita dan pria.Wanita hanya dibatasi oleh peranan internal dimana hanya mengurusi persoalan yang ada di dalam rumah tangga saja, sedangkan pria memiliki peranan yang lebih dari wanita dan bervariasi, tentunya di luar yang berhubungan dengan urusan kerumahtanggaan.Sehingga timbul sebuah asumsi bahwa di dalam keluarga pria lebih memiliki kekuasaan dalam pengambilan keputusan.

Subordinasi ialah sikap atau tindakan masyarakat yang menempatkan perempuan pada posisi yang lebih rendah dibanding laki-laki. Nilai-nilai yang berlaku dimasyarakat telah memisahkan dan memilah-milah peran-peran gender, laki-laki dan perempuan. Perempuan dainggap bertanggung jawab dan memilii peran dalm urusan domestik atau reproduksi, sementara laki-laki dalm urusan publik atau produksi. Hal itu dapat terjadi karena keyakinan terhadap jenis kelamin yang dianngap lebih penting atau lebih unggul ialah laki-laki, telah dikonsepkan secara turun temurun.

Posisi jenis kelamin yang melahirkan prasangka gender berdampak pada pola hubungan antara laki-laki dan perempuan. Laki-laki menjadi superordinat dalam berbagai aspek kehidupan.Hubungan dengan perempuan, dijalankan berdasarkan pemahaman mengenai superioritas laki-laki dan inferioritas terhadap perempuan. Sebagai jenis kelamin yang yang memosisikan diri lebih unggul, laki-laki menciptakan legimitasi yang terbentuk melalui lembaga- lembaga patriarki guna melanggengkan hegemoni terhadap kedudukan perempuan.

Tindakan subordinasi dan represi oleh laki-laki terhadapa perempuan merupakan bagian dari sistem kontrol yang berupaya menegaskan kedudukan yang tidak setara anatara dua jenis kelamin tersebut. Berdasarkan hal ini, prasangka gender kemudian muncul sebagai upaya diskriminasi terhadap eksistensi pihak subordinat. Pandangan dan perlakuan laki-laki terhadap perempuan yang meresap dan dilegalkan oleh lembagalembaga patriarki membuat kaum perempuan mengikuti ideologi tentang ketidaksetaraan gender tersebut.Pada akhirnya perempuan tidak hanya memunculkan perilaku inferior dalam hubungannya dengan pihak laki-laki.Akan tetapi, perempuan juga membentuk citra 
inferior dan mendorong diri sendiri kepada posisi subordinat dalam hubungannya dengan sesema perempuan.

Membahas masalah pandangan dan perlakuan laki-laki terhadap perempuan, hal yang ingin diungkapkan secara rinci ialah perihal subordinasi dan dampaknya terhadap hubungan yang terbangun antara laki-laki dengan perempuan, atau antara perempuan dengan perempuan.

Mengingat subordinasi dalam bentuk operasi dan peremehan eksistensi perempuan merupakan sebuah manifestasi prasangka gender, uraian pada bagian ini berusaha mengungkapkan bentuk-bentuk hubungan yang terjalin antara laki-laki dan perempuan, atau antara perempuan dengan perempuan yang telah mengakibatkan kemunculan hal tersebut.Perbedaan gender telah melahirkan ketidakadilan geder yang berimbas pada posisi yang disandang oleh kaum perempuan. Menurut Fakih (1996:147157), perbedaan gender yang berdasar pada anggapan dan penilaian oleh konstruksi sosial pada akhirnya menimbulkan sifat dan stereotip yang oleh masyarakat dianggap sebagai ketentuan kodrati atau bahkan ketentuan tuhan. Sifat dan stereotip yang sebetulnya merupakan konstruksi ataupun rekayasa sosial dan akhirnya terkukuhkan menjadi kodrat kultur, dalam proses yang panjang dan akhirnya telah mengakibatka terkondisikannya beberapa posisi perempuan. Pelanggengan posisi subordinasi, stereotype dan kekerasan terhadap kaum perempuan ini tidak secara sadar juga dijalankan oleh ideologi dan kultur patriarki, yakni ideologi yang berdasarkan pada kekuasaan laki-laki. Ideologi ini ada di kepala kaum laki-laki maupun perempaun, juga dalam tafsir agama yang sangat mempengaruhi kebijakan Negara dan birokrasi pembangunan.

Beberapa hal bisa disimpulkan dari reflaksi ini,pertama bahwa memperjuangkan perempuan tidak sama dengan perjuangan perempuan melawan laki-laki. Persoalan penindasan terhadap perempuan bukanlah persoalan kaum laki-laki, melainkan persoalan sistem dan struktur ketidakadilan masyrakat dan ketidakadilan gender adalah salah satunya. Gerakan kaum perempuan adalah gerakan tranformasi dan bukan gerakan untuk membalas dendam laki-laki. Jika demikian, gerakan transformasi perempuan adalah suatu proses gerakan untuk menciptakan hubungan antara sesame manusia yang secara fundamental lebih baik dan baru. Hubungan ini meliputi hubungan ekonomi, politik, cultural, ideology, lingkungan dan termasuk di dalamnya hubungan antara laki-laki danperempuan.

Dalam masalah gender, teori sosial-konflik terkadang diidentikkan dengan teori Marx, karena begitu kuatnya pengaruh Marx di dalamnya. Marx yang kemudian 
dilengkapi oleh F. Engels, mengemukakan suatu gagasan menarik bahwa perbedaan dan ketimpangan gender antara laki-laki dan perempuan tidak disebabkan oleh perbedaan biologis, tetapi merupakan bagian dari penindasan kelas yang berkuasa dalam relasi produksi yang diterapkan dalam konsep keluarga. Hubungan laki-laki dan perempuan tidak ubahnya dengan hubungan ploretar dan borjuis, hamba dan tuan, atau pemeras dan yang diperas. Dengan kata lain, ketimpangan peran gender dalam masyarakat bukan karena kodrat dari Tuhan, tetapi karena konstruksi masyarakat.

\section{METODE PENELITIAN}

Penelitian ini merupakan penelitian kualitatif yang bersifat deskriptif dengan memfokuskan penelitian pada "Subordinasi terhadap anak perempuan dalam keluarga di Desa Perangian Kecamatan Baraka Kabupaten Enrekang.Informan ditentukan secara purposive sampling, sumber data yaitu data primer dan data sekunder.Teknik pengumpulan data yaitu observasi, wawancara dan dokumentasi, kemudian dianalisis melalui tahapan pengumpulan data (data collection), menganalisis data,penarikan kesimpulan (conclusion) dan menggunakan teknik keabsahan data triangulasi sumber, waktu, dan teknik.

\section{PEMBAHASAN}

Perbedaan gender telah melahirkan ketidakadilan geder yang berimbas pada posisi yang disandang oleh kaum perempuan. Perbedaan gender yang berdasar pada anggapan dan penilaian oleh konstruksi sosial pada akhirnya menimbulkan sifat dan stereotip yang oleh masyarakat dianggap sebagai ketentuan kodrati atau bahkan ketentuan tuhan. Sifat dan stereotip yang sebetulnya merupakan konstruksi ataupun rekayasa sosial dan akhirnya terkukuhkan menjadi kodrat kultur, dalam proses yang panjang dan akhirnya telah mengakibatka terkondisikannya beberapa posisi perempuan seperti subordinasi.

Perempuan seringkali dinilai sebagai makhluk yang lebih inferior daripada lakilaki dalam kehidupan sehari-hari.Perempuan dianggap sebagai makhluk yang lemah sehingga harus berada di bawah kekuasaan laki-laki.Perbedaan yang terjadi terhadap kaum perempuan mulai dari lingkungan keluarga, tempat tinggal hingga lingkungan kerja.Kaum perempuan seringkali kurang mendapatkan kesempatan untuk berkiprah dalam kehidupan sosial apabila dibandingkan dengan laki-laki.Fenomena, realitas, dan fakta-fakta sosial budaya sebagaimana dikemukakan memperlihatkan dengan jelas 
adanya relasi laki-laki dan perempuan yang asimetris yang timpang, yang tidak setara, dan diskriminati.

Mansour Fakih (2001: 12) menyebutkan bahwa perbedaan gender melahirkan ketidakadilan bagi laki-laki dan terutama bagi perempuan. Menurutnya terdapat banyak manifestasi ketidakadilan gender diantaranya stereotip dan subordinasi. Subordinasi yaitu anggapan bahwa perempuan itu irrasional atau emosional sehingga perempuan tidak dapat memimpi. Masyarakat menganggap bahwa semua jenis "pekerjaan perempuan", seperti pekerjaan domestik, dianggap dan dinilai lebih rendah dibandingkan dengan jenis pekerjaan yang dianggap sebagai pekerjaan laki-laki. Selain itu, pekerjaan perempuan dinilai sebagai pekerjaan tidak produktif dan tidak diperhitungkan dalam statistik negara.Akibatnya, upah yang diberikan kepada perempuan lebih sedikit daripada laki-laki walaupun tidak berarti beban kerja perempuan lebih ringan daripada beban kerja lakilaki.Perbedaan ranah inilah yang sering menstereotipekan perempuan sebagai jenis kelamin yang dianggap kurang mampu untuk menjalankan fungsi-fungsi ekonomi.Lakilaki dianggap lebih mampu untuk bertindak dan menjalankan sumber daya ekonomi seperti memimpin dan memanajemen perusahaan.

Subordinasi perempuan yang 'lumrah' berkembang dalam budaya patriarkhi tersebut, menempatkan perempuan pada posisi yang kurang menguntungkan baik dari segi sosial, ekonomi maupun politik. Karena bagaimanapun, posisi ekonomi yang lemah berpengaruh signifikan terhadap proses komunikasi dan negosiasi dalam forum pengambilan keputusan, baik itu di rumah tangga ataupun di masyarakat luas. Sebenarnya, secara sederhana bisa kita analisa bahwa jika saja perempuan dan laki-laki tidak lagi dibedakan peranan gendernya, maka peningkatan ekonomi keluarga maupun skala ekonomi makro di dalam pembangunan daerah akan lebih cepat terwujud karena terbukanya kesempatan yang sama bagi perempuan dan laki-laki dalam mendapatkan manfaat dan prioritas dari hasil-hasil pembangunan.

Ideologi gender dalam prosesnya telah menciptakan berbagai konstruksi sosial. Konstruksi sosial ini berproses melalui tradisi sehingga orang menjadi tidak sadar bahwa yang terjadi adalah buatan manusia. Dalam proses sejarah manusia, masyarakat mencampuradukan pengertian jenis kelamin atau seks sehingga terjadi salah pengertian. Pengertian nature dan nurture dicampuradukkan sehingga masyarakat menjadi tidak dapat membedakan apa yang sebenarnya dapat berubah dan apa yang tidak. Teori nature menganggap bahwa perbedaan psikologis antara laki-laki dan perempuan disebabkan oleh perbedaan biologis dua insan tersebut. Teori nurture menganggap bahwa perbedaan laki- 
laki dan perempuan disebabkan oleh proses belajar manusia dari lingkungannya. Secara nature perbedaan laki-laki dan perempuan kodrat dari Tuhan Yang Maha Esa.Akan tetapi, secara nurture perbedaan laki-laki dan perempuan ditentukan oleh masyarakat di lingkungannya sendiri.Sesuatu yang telah membudaya bahwa laki-laki dipandang mempunyai kekuatan yang lebih baik dibandingkan perempuan.Laki-laki memiliki fisik yang lebih kuat.Laki-laki lebih bertindak lebih rasional, sedangkan perempuan lebih banyak irasional.Akibatnya, dalam kehidupan terjadilah ketimpangan-ketimpangan. Perempuan dianggap lebih rendah daripada laki-laki dalam berbagai sisi kehidupan social

Dalam perkembangan selanjutnya, hal itu dapat menyebabkan terbentuknya pandangan bahwa posisi perempuan adalah subordinat.Laki-laki selalu memimpin sedangkan perempuan menjadi pihak yang selalu dipimpin.Hubungan antara laki-laki dan perempuan menjadi tidak sejajar. Tidak duduk sama rendah dan berdiri sama tinggi (peribahasa), tetapi kedudukannya terjadi secara vertikal. Laki-laki berada di atas, perempuan berada di bawah.Kehidupan perempuan secara sosial berada di bawah bayang-bayang laki-laki.Subordinasi Perempuan, menyebabkan muncullah stereotip.

Stereotip merupakan bentuk pembakuan suatu pandangan terhadap kelompok manusia dengan memberi ciri-ciri tertentu, tanpa memperhatikan kemampuan perseorangan.Pembakuan pandangan tentang kedudukan perempuan dan laki-laki.Sampai sekarang pemahaman terhadap perempuan sebagai stereotip masih cukup besar.Hal ini diakui masih adanya kecenderungan persepsi yang membenarkan bahwa dalam hal pembagian warisan, perempuan berhak memperoleh setengah bagian dari laki-laki.Begitu halnya dalam kegiatan berpolitik, para pemuka agama masih menganggap bahwa perempuan kedudukannya lebih rendah daripada laki-laki.

Perempuan sebagai manusia yang memiliki sifat insani, seperti halnya laki-laki, perempuan akan belajar tentang kehidupan berdasarkan pengalamannya. Akan tetapi, perbedaan secara biologis antara laki-laki dan perempuan menyebabkan perbedaan pengalaman. Perempuan harus merasakan haid, hamil, melahirkan, menyusui yang merupakan pengalaman yang tidak akan pernah terjadi pada laki-laki pada umumnya. Hal inilah yang lebih mendorong perempuan berusaha memelihara kehidupan dengan belajar dari pengalamannya sendiri dan pengalaman kaumnya.

Secara akal sehat sudah sepantasnya apabila perempuan bebas menentukan apa yang akan dilakukan di dalam melaksanakan tugas manajemen kehidupan ini. Akan tetapi, dalam realitas kehidupan, perempuan tidak lagi mempunyai hak untuk mengatur kehidupan.Segala aspek kehidupan ditentukan oleh suatu kekuatan di luar kehidupan 
kaum perempuan.Kekuatan tersebut adalah politik.Politik yang menempatkan perempuan di bawah laki-laki atau para suami.

\section{KESIMPULAN}

1) Dampak negatif subordinasi terhadap anak perempun dalam keluarga yaitu membatasi perempuan untuk mendapatkan akses dan manfaat serta melakukan kontrol dalam dunia pembangunan. selain itu ketidakadilan subordinasi juga berdampak pada keadaan psikologi perempuan seperti adanya perasaan cemburu, iri dan perasaan sedih. Sedangkan dampak positif subordinasi terhadap anaka perempuan yaitu memberikan semangat bagi kaum perempuan untuk memperjuangkan hak dan posisi yang sama seperti kaum laki-laki.

2) Terjadinya subordinasi terhadap anak perempuan dalam keluarga di Desa Perangian Kecamatan Baraka Kabupaten Enrekang disebabkan oleh dua faktor yaitu kodrat (nature) dan kontruksi sosial (nurture). Secara nature perbedaan laki-laki dan perempuan kodrat dari Tuhan Yang Maha Esa. Akan tetapi, secara nurture perbedaan laki-laki dan perempuan ditentukan oleh masyarakat di lingkungannya sendiri.

\section{DAFTAR PUSTAKA}

Fakih, Mansur.(1996). Analisis Gender dan Transformasi Sosial. Yogyakarta: Pustaka Belajar.

Ihromi, Tapi Omas dan Achie, S Luhulima,.(2007). Hak Azasi Perempuan Instrument Hukum Untuk Mewujudkan Keadilan Gender / Kajian Wanita dan Gender Edisi III.Jakarta : Yayasan Obor Indonesia

Jones, PIP. (2010). Pengntar Teori-Teori Sosial.Jakarta : Yayasan Pustaka Obor Indonesia.

Mosse, Julia, Cleves. (1996). Gender dan Pembangunan.Yogyakarta : pustaka Pelajar.

Narwoko, J.Dwi dan Bagong, Suyanto,.(2004). Sosiologi Teks Pengantar dan Terapan.Surabaya : Kencana.

Nugroho, Riant. (2008). Gender dan Administrasi Publik.Yogyakarta : pustaka Pelajar.

Prambudi, Anas. (2012). Subordinasi Dalam Bias Gender. Skripsi tidak diterbitkan : Skripsi Fakultas Ilmu Pengetahuan Budaya UI.

Rachman, Deni. DKK.(2006). Jurnal Perempuan Untuk Pencerahan dan Kesetaraan.Jakarta : Yayasan Jurnal Perempuan. 
Ritzer, George. (2012). Teori Sosiologi (Dari Sosiologi Klasik Sampai Perkembanagan Terakhir Postmodern). Yogyakarta: Pustaka belajar.

Rifai, Muhammad. (2011). Studi Tentang Makna Pekerjaan Juru Parkir Bagi Perempuandi Kota Makassar. Skripsi tidak diterbitkan.Skripsi Fakultas Ilmu Sosial Universitas Negeri Makaasar.

Sarderson, Stephenk. (2011). Makro Sosiologi.Jakarta : Rajawali Pers.

Soyomukti, Nurani. (2010). Pengantar Sosiologi.Trenggalek : Ar. Ruzz Media.

Sugihastuti dan Istana Hadi Saptiawan. (2007). Gender dan Inferioritas Perempuan.Yogyakarta : Pustaka Belajar.

Sugiyono.(2013). Metode Penelitian Kuantitatif, Kualitatif, dan R\&D. Bandung : Alfabeta

Syamsuri, Andi, Sukri. (2013). Pedoman Penulisan Skripsi. Makassar: Unismuh Makassar.

Usman, Husnaini dan Purnomo Setiady Akbar .(2009). Metodologi Penelitian Sosial.Jakarta : Bumi Aksara.

Widaningsih, Lilis. (2014).Relasi gender dalam keluarga:Internalisasi nilai-nilai kesetaraan Dalam memperkuat fungsi keluarga (http://kelompok9relasigender.blogspot.com/2014/12/ebook-relasi-gender-dalamkeluarga.html), diakses 12 Desember 2014). 